Opailable online on 15.07.2018 at http://jddtonline.info
O 2011-18, publisher and licensee JDDT, This is an Open Access article which permits unrestricted non-
commercial use, provided the original work is properly cited

Open $\odot$ Access

Research Article

\title{
DESIGN AND DEVELOPMENT OF CONTROLLED POROSITY OSMOTIC TABLETS OF GARCINIA INDICA EXTRACT
}

\author{
Jagtap Prajakta Chandrakant ${ }^{* 1,2}$, Prakya Vijayalakshmi ${ }^{3}$, Bhise Kiran Sanjay ${ }^{1}$ \\ ${ }^{1}$ Department of Pharmaceutics, MCE's Allana College of Pharmacy, K. B. Hidayatullah Road, Azam Campus, Camp, Pune, \\ Maharashtra, India \\ ${ }^{2}$ Department of Pharmaceutical sciences, Jawaharlal Nehru Technological University Hyderabad, Telangana, India \\ ${ }^{3}$ Department of Pharmaceutics, Siddhartha Institute of Pharmacy, Ghatkesar, Hyderabad, India
}

\section{ABSTRACT}

The present study deals with the development and evaluation of controlled porosity osmotic pump (CPOP) tablets containing inclusion complexes of methanolic extract of Garcinia indica fruit rind. Wet granulation method was used for the development of core tablets. Core tablets were incorporated with different concentrations of sodium chloride as osmogen and additives. The CPOP tablets were coated with cellulose acetate as a wall forming material and HPMC acts as pore forming material in SPM. The formulated tablets were evaluated for FTIR, DSC, pre-compression parameters, post compression parameters, in vitro drug release study and scanning electron microscopy study. The optimized formulation had no significant effect on the $\mathrm{pH}$ and agitation intensity. SEM images revealed that no pores were found before dissolution and after dissolution had shown the porous nature of the membrane. It was found that the optimized formulation (P4) delivers a drug at a zero-order rate for 12 hours. Short term stability study at $40 \pm 2^{\circ} \mathrm{C} / 75 \pm 5 \% \mathrm{RH}$ for the months on the optimized formulation indicated that there was no significant change in weight variation, \% friability, drug content and in vitro drug release.

Keywords: Osmotic system, cellulose acetate, pore former, controlled porosity, Garcinia indica

Article Info: Received 18 March, 2018; Review Completed 06 June 2018; Accepted 12 June 2018; Available online 15 July 2018

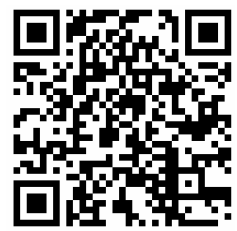

Cite this article as:

JagtapPC, Prakya V, Bhise KS, Design and development of controlled porosity osmotic tablets of Garcinia indica extract, Journal of Drug Delivery and Therapeutics. 2018; 8(4):161-169

DOI: http://dx.doi.org/10.22270/jddt.v8i4.1752

Prajakta Chandrakant Jagtap, Department of Pharmaceutics, M.C.E. Society's Allana College of Pharmacy, K. B. Hidayatullah Road, Azam Campus, Camp, Pune 01,Maharashtra, India

\section{INTRODUCTION}

In recent years, considerable attention has been focused on the development of novel drug delivery systems (NDDS). Once-daily controlled release preparation is often desirable. However, drug release from oral controlled release dosage forms may be affected by $\mathrm{pH}$, gastric motility, and presence of food ${ }^{1,2}$. Osmotic devices are most promising strategy based system for controlled drug delivery as they provides greater effectiveness in the treatment of chronic conditions by providing zero order drug release and which may reduce side effects and also better patient compliance.
The present study is to develop controlled porosity osmotic pump tablets. CPOP tablets were developed where the delivery orifices were formed by the incorporation of a leachable component in Semi permeable membrane (SPM) ${ }^{3}$. The core is coated with cellulose acetate containing in situ micro pore former HPMC. Once CPOP tablets come in contact with the aqueous environment of biological system the water soluble component dissolves and an osmotic pumping system is created in the core. Hence water diffuses into the core though the micro porous membrane setting up an osmotic gradient and thereby controlling the release of drug ${ }^{4,5,6}$. 
Garcinia indica (dried rind known as 'kokum'), family Clusiaceae, a tropical fruit, can be viewed as a wonder berry that has a myriad of health benefits and also pharmacologically studied for its antioxidative, chelating, free radical scavenging, anticancer, antiinflammatory, and antiulcer activities ${ }^{7}$. The methanolic extract of Garcinia indica fruit rinds was prepared using soxhlet apparatus. It has significant antioxidant and cytotoxic activity ${ }^{8}$. Therefore the extract was used for further formulation development studies.

\section{MATERIALS AND METHODS}

Fresh kokum fruits were collected and authenticated by Botanical Survey of India, Pune, Maharashtra, India. Cellulose Acetate was procured from Signet Chemicals Corporation Pvt. Ltd., Mumbai, $\mathrm{NaCl}$, HPMC, hydroxypropyl-beta-cyclodextrin (HP-ß-CD) was procured from Loba chem. Pvt. Ltd., Mumbai. Rest of the chemicals and reagents were of Analytical grade.

\section{Methods:}

\section{Phase Solubility Analysis for Garcinia indica extract}

Phase solubility studies of Garcinia indica extract with different concentrations of hydroxypropyl-betacyclodextrin (HP-B-CD) were performed according to the method described by Higuchi and Connors to determine stoichiometric proportions of extract with HPB-CD ${ }^{9-10}$. The data were used to determine stability constant of the complexes. For this, the stock solution of $10 \mathrm{mM}$ HP-ß-CD were prepared using distilled water. The stock solution was diluted with distilled water to give millimole solutions in the range of 02 to $10 \mathrm{mM}$ HPß-CD solutions. $20 \mathrm{ml}$ of each solution was filled in screw capped vials and the excess quantity of the drug was added to each vial separately. The vials were kept for shaking at ambient temperature for $48 \mathrm{hrs}$ using a lab shaker (Remi). After $48 \mathrm{hrs}$ of shaking to achieve equilibrium, $2 \mathrm{ml}$ aliquots are withdrawn at $1 \mathrm{hr}$ interval and filtered through Whatman no.1 filter paper. The filtered samples are diluted suitably and assayed for drug content by specific UV method against a blank.

\section{Preparation of inclusion complexes}

Preparation of solid complexes of Garcinia indica extract with HP-ß-CD was performed by the solvent evaporation method ${ }^{11-13}$. Extract with $\mathrm{HP}-3-\mathrm{CD}$ in different molar ratios $(1: 1$ and 1:2) were taken. First cyclodextrin placed in methanol-water system (9:1) with continuous stirring on linear motion shaker (Spectra lab Whirlmatic, Mumbai; Model No.TH100) for about $24 \mathrm{~h}$. The inclusion complex was obtained as dry powder by evaporating the solvent at a temperature above $70^{\circ} \mathrm{C}$ or sufficient to evaporate water using rotary evaporator and the complexes were collected, weighed, stored in glass vial and dried at room temperature. The same procedure was adopted to prepare HP- $\beta-C D$ complexes.

\section{Compatibility studies of inclusion complexes:}

\section{Fourier Transform Infrared Spectroscopy (FTIR)}

In this method inclusion complexes of extract as well as the excipients were mixed thoroughly with potassium bromide (1:100) for 3-5 minutes in a mortar and compressed into disc using hydraulic press ${ }^{14}$. The pellet was kept in the sample holder and scanned from 4000 to $400 \mathrm{~cm}-1$ in FTIR spectrophotometer (Jasco, Japan).

\section{Differential Scanning Calorimetry (DSC)}

Physical mixtures of drug and individual excipients in the ratio of $1: 1$ were taken and examined in DSC. Individual samples as well as physical mixture of drug and excipients were weighed to about $5 \mathrm{mg}$ in DSC pan. The sample pan was crimped for effective heat conduction and scanned in the temperature range of 50$300^{\circ} \mathrm{C}$. Heating rate of $20^{\circ} \mathrm{C} \mathrm{min}^{-1}$ was used and the thermogram obtained was reviewed for evidence of any interactions.

\section{Methods}

\section{Preparation of CPOP tablets}

The core tablets of Garcinia indica inclusion complexes were prepared by wet granulation technique with varying ratios of the osmogen. Drug and all the ingredients except lubricants were weighed and passed through 30 mesh screen. The ingredients were manually blended homogenously in a mortar by way of geometric dilution. The mixture was moistened with non aqueous solution and granulated through sieve No.30 and dried in a hot air oven at $60^{\circ} \mathrm{C}$ for sufficient time (3-4 hrs). The dried granules were passed though sieve No.30 and blended with magnesium stearate. The homogenous blend was then compressed into tablets with standard concave punches using 10 station rotary compression machines (Mini press, Karnavati, India).

Table 1: Composition of controlled porosity osmotic pump tablets of Garcinia indica

\begin{tabular}{|l|c|c|c|c|c|c|}
\hline Ingredients & P1 (50\%) & P2 (60\%) & P3 (70\%) & P4 (80\%) & P5 (90\%) & P6 (0\%) \\
\hline GI+ HPßCD & 300 & 300 & 300 & 300 & 300 & 300 \\
\hline NaCl & 75 & 90 & 105 & 120 & 135 & -- \\
\hline Sodium Stach glcollate & 4 & 4 & 4 & 4 & 4 & 4 \\
\hline Di calcium Phosphate & 69 & 54 & 39 & 24 & 09 & 144 \\
\hline Talc & 1 & 1 & 1 & 1 & 1 & 1 \\
\hline Mg stearate & 1 & 1 & 1 & 1 & 1 & 1 \\
\hline Total wt & $450 ~ \mathbf{~ g ~}$ & \multicolumn{5}{|l}{} \\
\hline
\end{tabular}




\section{Coating of core tablets ${ }^{15}$ :}

The coating solution was prepared taking required ingredients from table 2 and acetone was added quantity sufficient maintaining proper viscosity of solution. The coatings of tablets were performed by using R \& D coater. Hot air is supplied to tablet bed by rotating lower speed 10-15 rpm initially. The coating of tablets was carried out with the rotation speed of 15-30 $\mathrm{rpm}$. The spray rate and atomizing air pressure were 1$2 \mathrm{ml} / \mathrm{min}$ and $1-2 \mathrm{~kg} / \mathrm{cm} 2$ respectively. Inlet and outlet air temperature were $35^{\circ} \mathrm{C}$ and $55^{\circ} \mathrm{C}$ respectively. Coated tablets were dried at $50^{\circ} \mathrm{C}$ for $12 \mathrm{hrs}$. The process was continued until $10 \%$ weight gain of the tablets. The coated tablets were rotated for a further 15 min under blower.

Table 2: Coating composition for controlled porosity osmotic pump tablets

\begin{tabular}{|l|l|}
\hline Ingredients & Quantity \\
\hline Cellulose Acetate 398-10 & 3 grams \\
\hline HPMC & 4 grams \\
\hline Castor oil & $2.5 \mathrm{ml}$ \\
\hline Acetone & $100 \mathrm{ml}$ \\
\hline
\end{tabular}

\section{Precompression parameters ${ }^{16}$}

\section{Evaluation of Granules:}

The prepared granules were evaluated for pre compression parameters such as angle of repose, bulk density, tapped density and compressibility index (Carr's index). Fixed funnel method was used to determine angle of repose.

\section{Post compression parameters ${ }^{17-18}$}

\section{Thickness}

The uniformity of thickness was measured using digital vernier caliper. The average thickness of the tablet was calculated. The limit of the thickness deviation of each tablet is $5 \%$.

\section{Measurement of coat thickness}

Film was isolated from the tablets after $18 \mathrm{hrs}$ of dissolution and dried at $40^{\circ} \mathrm{C}$ for $1 \mathrm{hr}$. Thickness was measured by using electronic digital calipers (Absolute digimatic, Mitutoyo Corp. Japan)

\section{Hardness}

The hardness of tablets can be determined by using Monsanto hardness tester.

\section{Friability test}

Friability test of tablets was performed in a Roche friabilator. Twenty tablets of known weight (W1) were de-dusted in plastic chamber of friabilator for a fixed time of $25 \mathrm{rpm}$ for 4 minutes and weighed gain of weight (W2).The percentage of friability was calculated using the following equation.

$\%$ Friability $=\mathrm{F}=\left(1-\mathrm{W}_{2} / \mathrm{W}_{1}\right)$

Where, W1 and W2 are the weight of the tablets before and after the test respectively.

\section{Weight variation test}

The weight variation test is performed by weighing 20 tablets individually calculating the average weight and comparing the individual tablet weights to the average. The percentage weight deviation was calculated and then compared with USP specifications.

\section{Uniformity of drug content test}

Powder is made after triturating 10 CPOP tablets from each batch with mortar and pestle. The powder weight equivalent to one tablet was dissolved in a $100 \mathrm{ml}$ volumetric flask filled with $\mathrm{pH} 6.8$ phosphate buffer and kept on rotary shaker for $24 \mathrm{hrs}$. in order to completely extract the drug. The mixture was filtered, and the drug was assayed spectrophotometrically at 253 $\mathrm{nm}$.

\section{In -vitro Release Studies ${ }^{19}$ :}

In vitro drug release for preliminary and factorial batches was carried out using USP - type II dissolution apparatus (paddle type). The dissolution medium, 900 $\mathrm{ml}$ of $0.1 \mathrm{~N} \mathrm{HCl}$ at $37 \pm 0.5^{\circ} \mathrm{C}$, and $100 \mathrm{rpm}$ for first 2 hrs then replaced with 6.8 phosphate buffer and continued for $24 \mathrm{hrs}$. Aliquot volume of $5 \mathrm{ml}$ was withdrawn after every 1, 2, 4, 6, 8, 10, 12 and 24 hours and replaced with fresh 6.8 phosphate buffer. Collected samples were suitably diluted with phosphate buffer $(\mathrm{pH} 6.8)$ and analyzed at $253 \mathrm{~nm}$ using phosphate buffer (pH 6.8) as blank.

\section{Kinetics of Drug Release ${ }^{20}$}

In order to investigate the mode of release from tablets, the release data of formulation was analyzed zero order kinetics, first order kinetics, Higuchi model and Korsmeyer-Peppas and Hixson-Crowell equations to ascertain the kinetic modeling of drug release by using a PCP Disso Version 2.08 software, and the model with the higher correlation coefficient was considered to be the best model.

\section{Effect of Formulation variables ${ }^{21}$}

In order to optimize the formulation to release the drug at a constant zero-order release rate, level of pore former, effect of weight gain during coating, $\mathrm{pH}$ and agitation intensity were used as formulation variables.

\section{Effect of osmogen concentration}

Keeping all the parameters for tablet constant different osmogen concentrations were used to prepare tablets. The drug release was compared with the different osmogen concentration of formulated batches by using USP-II dissolution apparatus.

\section{Effect of pore former concentration}

To study the effect of different amount of pore forming agent on drug release, the varying concentration of pore former i.e. $2.5 \mathrm{gm}, 5 \mathrm{gm}, 7.5 \mathrm{gm}$ HPMC was used in coating.

\section{Effect of weight gain:}

To study the effect of weight gain of the coating on drug release, the core tablets of Garcinia indica 
inclusion complexes were coated with coating solution in order to achieve a weight gain of $8,10,12 \% \mathrm{w} / \mathrm{w}$.

\section{Effect of pH:}

In-vitro dissolution studies were performed using USP dissolution apparatus type II in different release media $(0.1 \mathrm{~N} \mathrm{HCl}$ phosphate buffer $\mathrm{pH} 6.8$, and 7.4) maintained at $37^{\circ} \mathrm{C} \pm 0.5^{\circ} \mathrm{C}$ and $100 \mathrm{rpm}$. The optimized formulation (F6) was selected for the study of effect of $\mathrm{pH}$.

Effect of agitation intensity: It is necessary to check that the effect of agitation intensity on the drug release. In-vitro dissolution studies was performed using USP dissolution apparatus type II in 6.8 Phosphate buffer maintained at $37^{\circ} \mathrm{C} \pm 0.5^{\circ} \mathrm{C}$. The optimized formulation (F6) was subjected to different Agitation intensities 50, 75 and $100 \mathrm{rpm}$. The responses were noted.

\section{Scanning Electron Microscopy ${ }^{22}$ :}

Coating membranes of formulation obtained before and after complete dissolution of core contents were examined for their porous morphology by scanning electron microscope.

\section{Stability study ${ }^{23}$ :}

The optimized formulation (P4) was packed in the strips of thick Aluminum foil laminated with PVC and stored in ICH certified stability chambers (Thermo lab, Stability chamber, Scientific Equipment's, Pvt. Ltd.) maintained at $40^{\circ} \mathrm{C}$ and $75 \% \mathrm{RH}$ for 6 months. The tablets were drawn periodically and evaluated for the appearance, drug content and dissolution profile.

\section{RESULT AND DISCUSSION}

\section{Phase solubility analysis of Garcinia indica extract}

On the complexation of the drug with HPß-CD, the effect of HPß-CD on the solubility, and the stability constant of HPß-CD complex formed were investigated by phase solubility studies. The phase solubility curve of Garcinia indica extract in the presence of HP $\beta-C D$ is shown in Figure 1. From this curve, it can be seen that the solubility of the extract increases due to the formation of an inclusion complex between extract and HP $\beta-C D$. A linear increase in solubility of extract was observed with an increase in concentration of HP $\beta$ $\mathrm{CD}$ in water. The phase solubility plot showed an $A_{L}$ type solubility curve, which indicates that only $1: 1$ drug-HP $\beta-C D$ inclusion complex was formed in solution. The apparent stability constant $\left(\mathrm{K}_{1: 1}\right)$ for the Garcinia indica extract: HP $\beta-C D$ complex was calculated from the solubility data and found to be $126.81 \mathrm{M}^{-1}$.

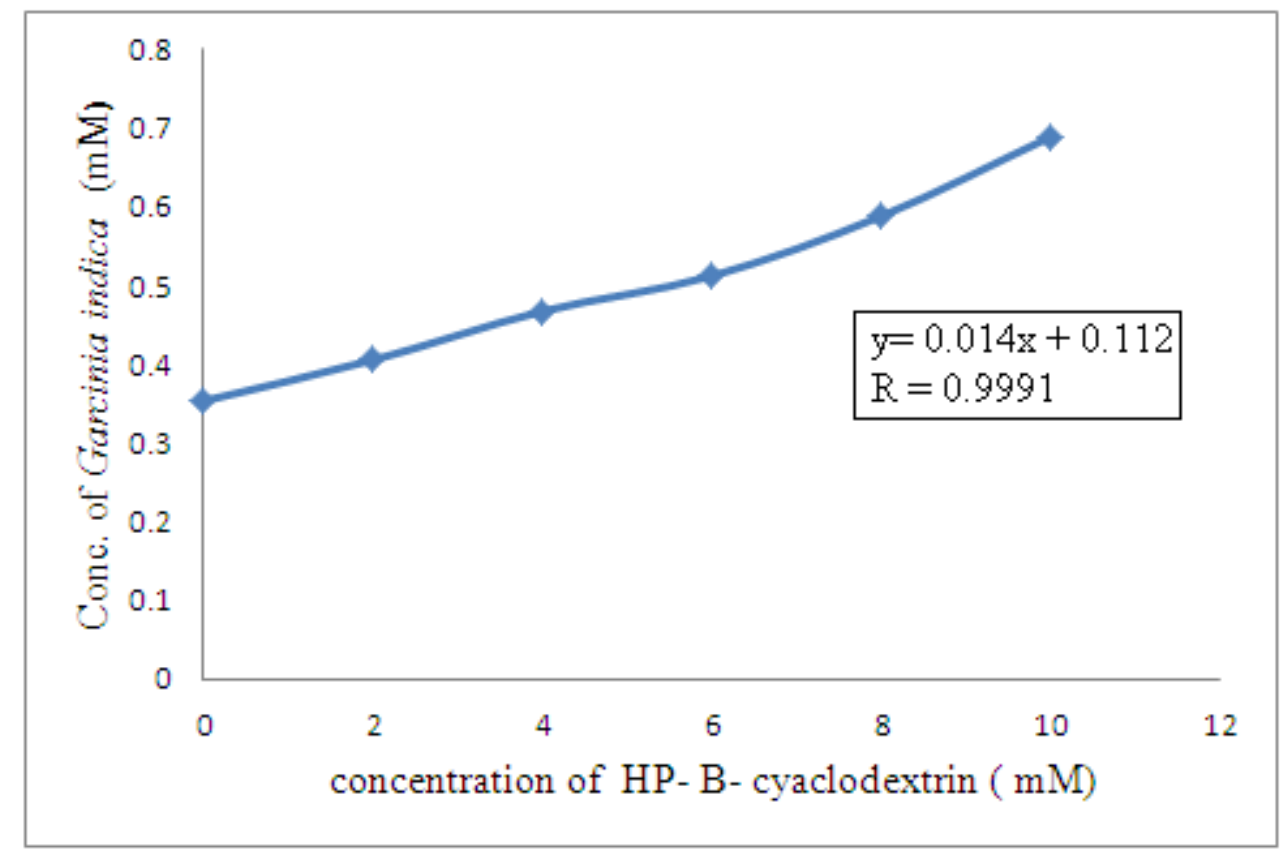

Figure 1: Solubility study of Garcinia indica and HP $\beta$ cyclodextrin complexes

\section{Compatibility studies:}

a) FTIR study: Drug polymer interactions were studied by FTIR. From the spectra it was observed that there was no interaction between the drug and excipients (Figure 2) as the characteristic peaks remained as such. 


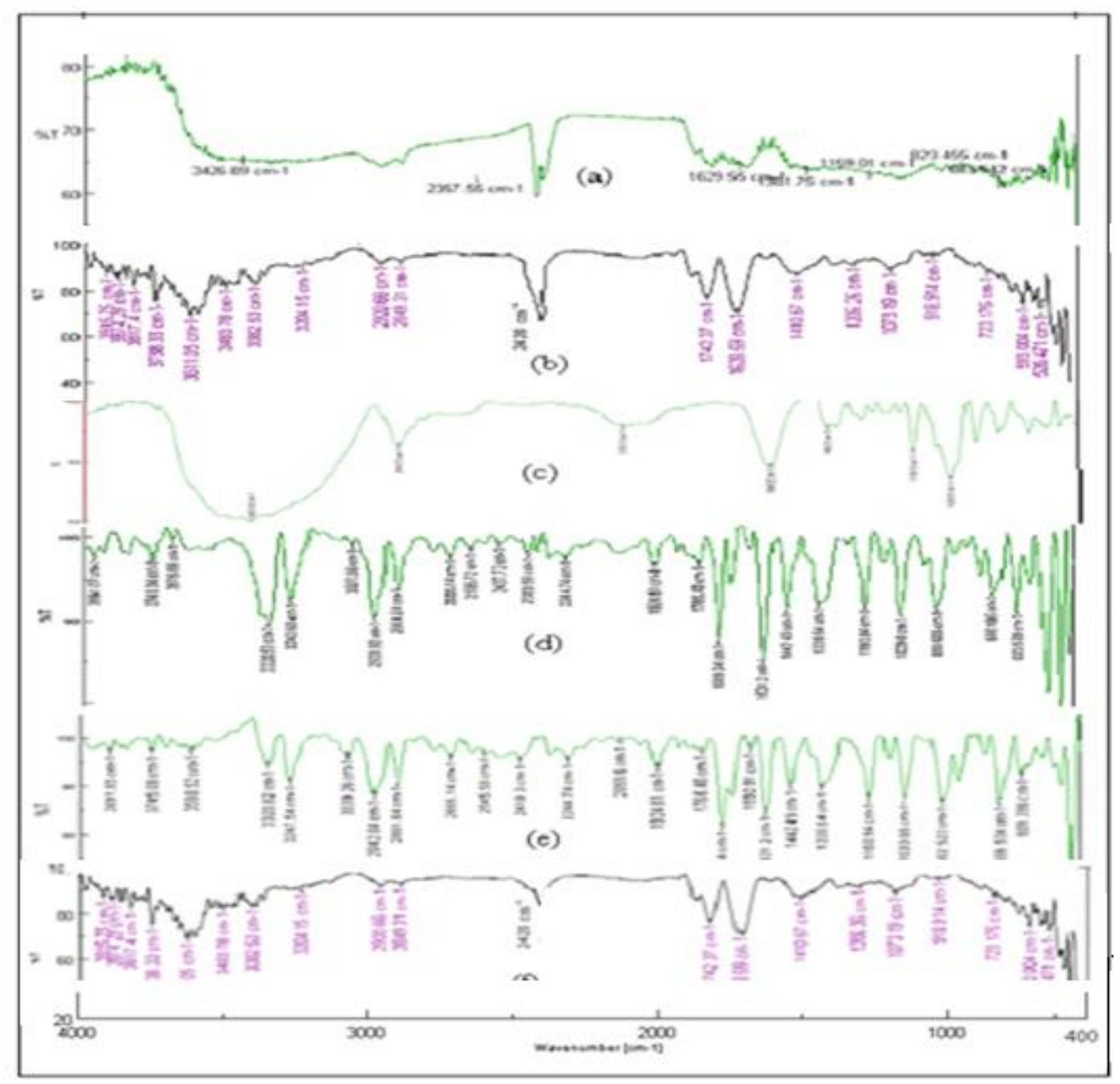

Figure 2: FTIR Analysis of a) Garcini indica Extract (b) Garcinia indica inclusion complex (c) Beta Cyclodextrin (d) $\mathrm{NaCl}$ (e) HPMC (f) Formulation

b) DSC study:

DSC thermogram is depicted in Figure 3 indicates that the endothermic peak of Garcinia indica extract at $93.5^{\circ} \mathrm{C}$ and the endothermic peak of formulation is showing at $102.2^{\circ} \mathrm{C}$. There were no significant changes in the endotherm peak between drug and formulation.

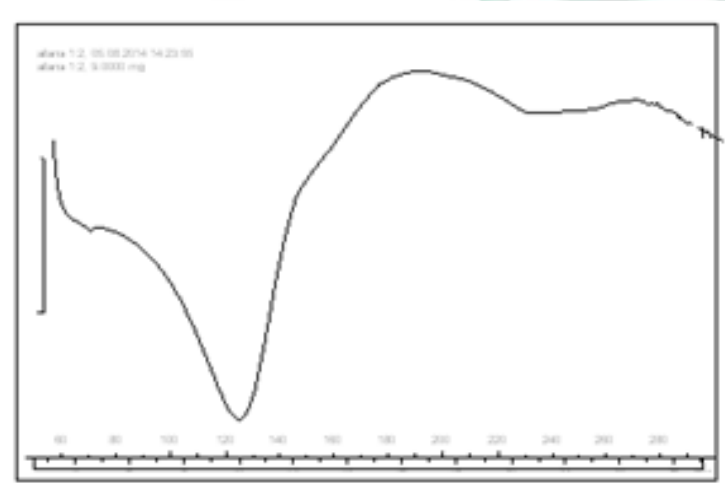

(a)

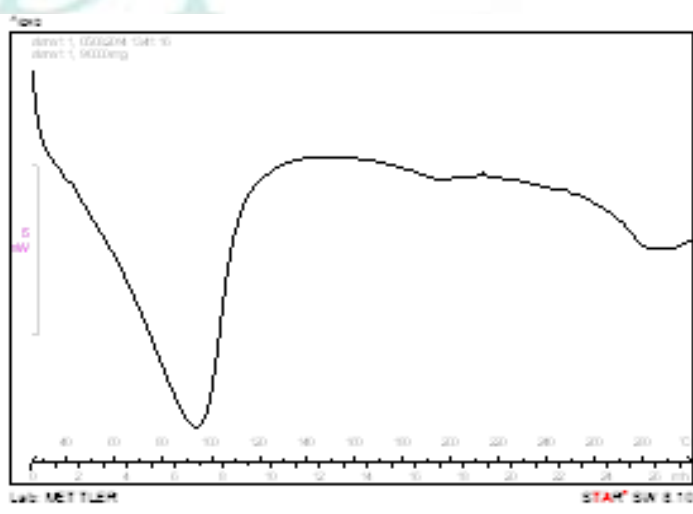

(b)

Figure 3: DSC Study of Garcinia indica extract and its formulation

\section{Precompression parameters}

The angle of repose of all formulations was within the range of $23.76^{\circ}-29.45^{\circ}$ indicative of excellent and good flow ability. The bulk density of powder was found to be between $0.72-0.77 \mathrm{gm} / \mathrm{cm} 3$. The tapped density of the granules of batches was found in the range of $0.78-$
$0.85 \mathrm{gm} / \mathrm{cm}^{3}$. The bulk density and tapped density was used to calculate the percent compressibility of the powder. The compressibility index of the powder was observed in range of $6.32 \%-13.25 \%$. The Hausner's ratio was found to be the range of 1.06-1.15 indicating good and fair flow ability. 
Table 3: Evaluation of granules

\begin{tabular}{|l|l|l|l|l|l|l|}
\hline Formulation & $\begin{array}{l}\text { Bulk Density } \\
\text { (gm/cc) }\end{array}$ & $\begin{array}{l}\text { Tapped } \\
\text { Density } \\
\text { (gm/cc) }\end{array}$ & $\begin{array}{l}\text { Carr's Index } \\
\mathbf{( \% )}\end{array}$ & $\begin{array}{l}\text { Angle of } \\
\text { Repose }(\mathbf{})\end{array}$ & $\begin{array}{l}\text { Hausner's } \\
\text { Ratio }\end{array}$ & $\begin{array}{l}\text { Flow } \\
\text { pattern }\end{array}$ \\
\hline P1 & $0.73 \pm 0.04$ & $0.78 \pm 0.04$ & $6.41 \pm 0.73$ & $26.93 \pm 0.85$ & $1.06 \pm 0.02$ & Good \\
\hline P2 & $0.72 \pm 0.09$ & $0.83 \pm 0.53$ & $13.25 \pm 1.11$ & $29.45 \pm 0.98$ & $1.15 \pm 0.05$ & Good \\
\hline P3 & $0.77 \pm 0.04$ & $0.85 \pm 0.05$ & $9.41 \pm 1.43$ & $24.82 \pm 1.11$ & $1.10 \pm 0.02$ & Excellent \\
\hline P4 & $0.74 \pm 0.07$ & $0.79 \pm 0.17$ & $6.32 \pm 0.86$ & $26.61 \pm 0.65$ & $1.06 \pm 0.03$ & Good \\
\hline P5 & $0.73 \pm 0.03$ & $0.80 \pm 0.06$ & $8.75 \pm 0.48$ & $23.76 \pm 0.73$ & $1.09 \pm 0.00$ & Excellent \\
\hline P6 & $0.76 \pm 0.05$ & $0.84 \pm 0.23$ & $9.52 \pm 0.93$ & $25.34 \pm 0.43$ & $1.10 \pm 0.07$ & Excellent \\
\hline
\end{tabular}

\section{Post Compression parameters}

All formulated tablet batches were evaluated for thickness, Hardness, weight variation, \% friability and drug content. All evaluated values were in acceptable limits. It is mentioned in table 4.

Table 4: Evaluation of preliminary batches

\begin{tabular}{|c|c|c|c|c|c|c|c|c|}
\hline \multirow{2}{*}{$\begin{array}{l}\text { Formula } \\
\text { code }\end{array}$} & \multicolumn{2}{|c|}{$\begin{array}{c}\text { Thickness* }(\mathrm{mm}) \\
\mathrm{N}=\mathbf{3}\end{array}$} & \multicolumn{2}{|c|}{$\begin{array}{l}\text { Hardness* } \\
\left(\mathrm{Kg} / \mathrm{cm}^{2}\right)\end{array}$} & \multicolumn{2}{|c|}{$\begin{array}{c}\text { Average* Weight } \\
\text { (gm) }\end{array}$} & \multirow[t]{2}{*}{$\begin{array}{l}\% \\
\text { Friability }\end{array}$} & \multirow{2}{*}{$\begin{array}{l}\text { Drug } \\
\text { content* } \\
(\%)\end{array}$} \\
\hline & $\begin{array}{l}\text { Before } \\
\text { coating }\end{array}$ & $\begin{array}{l}\text { After } \\
\text { coating }\end{array}$ & $\begin{array}{l}\text { Before } \\
\text { coating }\end{array}$ & $\begin{array}{l}\text { After } \\
\text { coating }\end{array}$ & $\begin{array}{l}\text { Before } \\
\text { coating }\end{array}$ & $\begin{array}{l}\text { After } \\
\text { coating }\end{array}$ & & \\
\hline P1 & $4.19 \pm 0.077$ & $4.69 \pm 0.04$ & $6.064 \pm 0.20$ & $7.73 \pm 0.21$ & $0.452 \pm 0.85$ & $0.477 \pm 0.46$ & 0.55 & $98.45 \pm 0.58$ \\
\hline $\mathrm{P} 2$ & $4.22 \pm 0.058$ & $4.72 \pm 0.05$ & $5.975 \pm 0.26$ & $7.05 \pm 0.17$ & $0.451 \pm 0.84$ & $0.476 \pm 0.49$ & 0.58 & $97.34 \pm 0.33$ \\
\hline $\mathrm{P} 3$ & $4.23 \pm 0.091$ & $4.73 \pm 0.05$ & $6.025 \pm 0.29$ & $7.56 \pm 0.09$ & $0.450 \pm 0.37$ & $0.475 \pm 0.43$ & 0.64 & $97.64 \pm 0.32$ \\
\hline $\mathrm{P} 4$ & $4.22 \pm 0.054$ & $4.72 \pm 0.09$ & $5.995 \pm 0.27$ & $7.75 \pm 0.07$ & $0.452 \pm 0.46$ & $0.477 \pm 0.45$ & 0.80 & $96.05 \pm 0.19$ \\
\hline P5 & $4.21 \pm 0.062$ & $4.71 \pm 0.07$ & $5.99 \pm 0.27$ & $7.30 \pm 0.22$ & $0.453 \pm 0.75$ & $0.478 \pm 0.44$ & 0.23 & $99.89 \pm 0.42$ \\
\hline P6 & $4.20 \pm 0.091$ & $4.70 \pm 0.08$ & $5.975 \pm 0$ & $7.21 \pm 0.34$ & $0.453 \pm 0.85$ & $0.479 \pm 0.43$ & 0.30 & $97.53 \pm 0.18$ \\
\hline
\end{tabular}

\section{In vitro dissolution study}

In vitro drug release for preliminary and factorial batches was carried out using USP - type II dissolution apparatus (paddle type). The percentage drug release from formulation P1 to P6 were denoted in figure 4 at the end of $12 \mathrm{hrs}$. Optimized Formulation P4 showed $69.48 \%$ drug release for $12 \mathrm{hr}$.

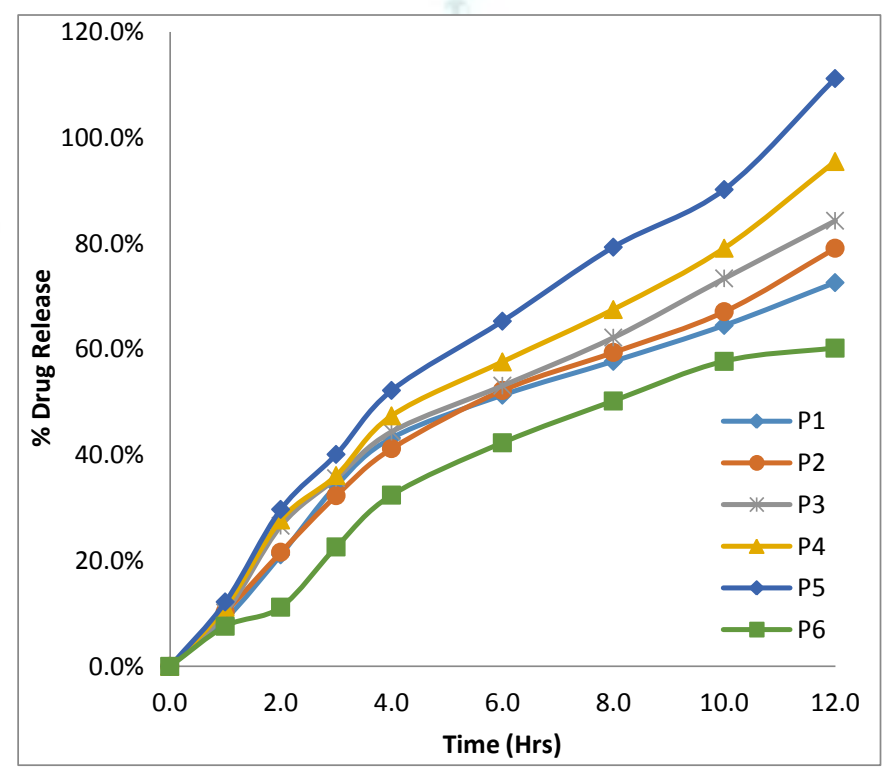

Figure 4: In vitro percentage drug release of preliminary batches.

\section{Kinetics of Drug Release}

In present study the dissolution were analyzed by PCP Disso Version 2.08 software to study the kinetics of drug release mechanism. The result supports Zero order release and Hixon crowell dissolution model. The $\mathrm{R}^{2}$ value of all dissolution models has been shown in Table 5. 
Table 5: Kinetics of drug release

\begin{tabular}{|l|c|c|c|c|c|c|c|c|c|c|c|}
\hline $\begin{array}{l}\text { Formulation } \\
\text { Code }\end{array}$ & \multicolumn{2}{|c|}{ Zero order } & \multicolumn{2}{|c|}{ First order } & \multicolumn{2}{|c|}{ Matrix } & \multicolumn{2}{c|}{ Peppas } & \multicolumn{2}{l|}{ Hixson crowell } & $\begin{array}{c}\text { Best } \\
\text { Fitting } \\
\text { Model }\end{array}$ \\
\hline & $\mathrm{R}$ & $\mathrm{K}$ & $\mathrm{R}$ & $\mathrm{K}$ & $\mathrm{R}$ & $\mathrm{K}$ & $\mathrm{R}$ & $\mathrm{K}$ & $\mathrm{R}$ & $\mathrm{K}$ & \\
\hline $\mathrm{F} 1$ & 0.9899 & 6.8469 & 0.9981 & 0.0896 & 0.9542 & 16.1448 & 0.9884 & 6.7655 & 0.9972 & -0.0272 & $\begin{array}{c}\text { First } \\
\text { Order }\end{array}$ \\
\hline F2 & 0.9979 & 5.3731 & 0.9973 & -0.0658 & 0.9439 & 12.5951 & 0.9974 & 5.3697 & 0.9987 & -0.0205 & $\begin{array}{l}\text { Hix- } \\
\text { Crowell }\end{array}$ \\
\hline F3 & 0.9961 & 5.7525 & 0.9963 & -0.0717 & 0.947 & 13.5111 & 0.9887 & 5.8219 & 0.9977 & -0.0222 & $\begin{array}{l}\text { Hix- } \\
\text { Crowell }\end{array}$ \\
\hline F4 & 0.9968 & 6.1271 & 0.9918 & -0.078 & 0.942 & 14.3649 & 0.9922 & 6.2647 & 0.9955 & -0.0239 & $\begin{array}{l}\text { Zero } \\
\text { order }\end{array}$ \\
\hline F5 & 0.998 & 7.2416 & 0.9796 & -0.0987 & 0.9281 & 16.873 & 0.9955 & 6.6871 & 0.9889 & -0.0295 & $\begin{array}{l}\text { Zero } \\
\text { order }\end{array}$ \\
\hline F6 & 0.989 & 4.3051 & 0.9889 & -0.0504 & 0.9172 & 10.0236 & 0.9856 & 3.1693 & 0.9893 & -0.0159 & $\begin{array}{l}\text { Hix- } \\
\text { crowell }\end{array}$ \\
\hline
\end{tabular}

\section{Effect of Formulation variables}

Effect of pore forming agent

The effect of pore forming agent on in vitro drug release was studied by coating the optimized formulation with varying concentration of pore former in coating solution (3\%, $4 \%$ and 5\% HPMC). It confirms that as the level of pore former increases the membrane becomes more porous after coming contact with aqueous environment resulting in faster drug release.

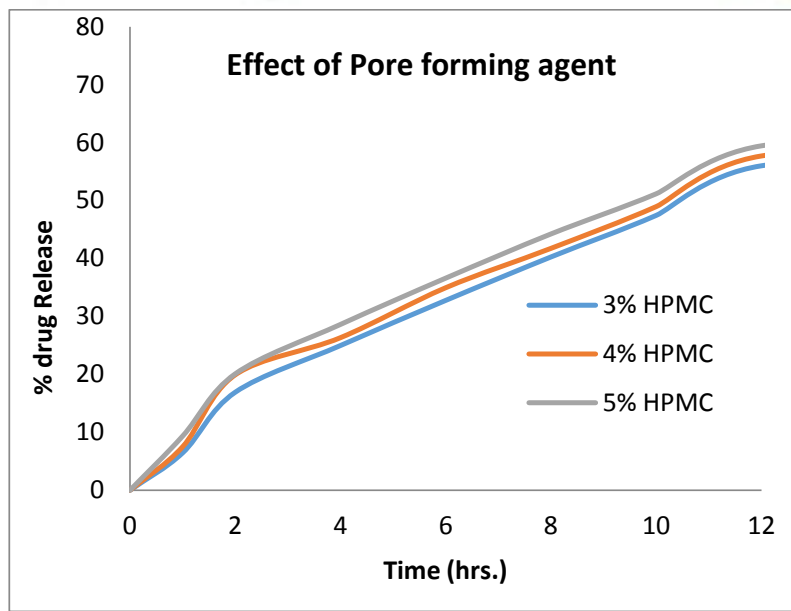

Figure 5: In vitro drug release profile of $(\mathbf{P 4})$ at different concentration of pore forming agent.

\section{Effect of Weight gain}

To study the effect of weight gain, optimized batch (P4) was coated with different weight gain $(8,10$ and $12 \%$ $\mathrm{w} / \mathrm{w})$ and was subjected to dissolution in Phosphate buffer 6.8 . It clearly shows that drug release, decreases with an increase in weight gain of membrane. The bursting effect of tablet was however absent throughout the dissolution study which assures that the formulations will remain intact in GIT without any incidence of dose dumping.

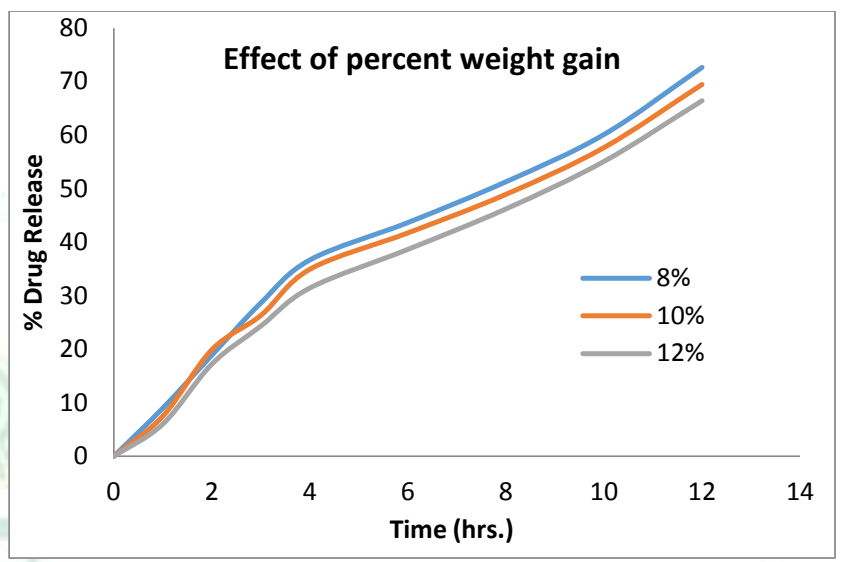

Figure 6: Effect of percent weight gain on drug release of optimized formulation

\section{Effect of pH}

To study the effect of $\mathrm{pH}$ on optimized batch (P4) was subjected to dissolution studies separately in $0.1 \mathrm{~N} \mathrm{HCl}$ for $2 \mathrm{hrs}$ and phosphate buffer 6.8 up to $12 \mathrm{hrs}$, Phosphate buffer 6.8 and Phosphate buffer 7.4 for 12 hrs. The system was independent of the $\mathrm{pH}$ as there was no difference in the drug release. Results demonstrating that the developed formulation shows $\mathrm{pH}$ independent release.

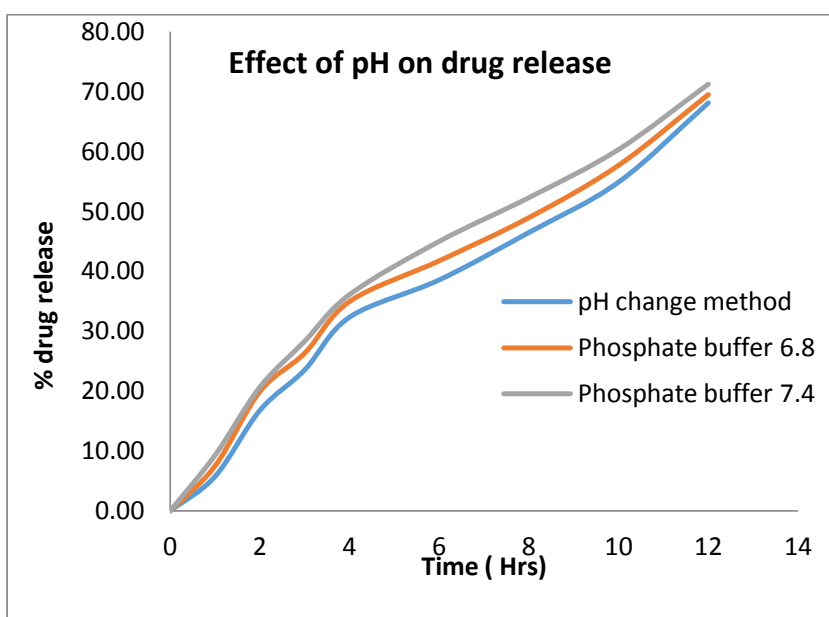

Figure 7: Influence of $\mathrm{pH}$ on drug release of optimized formualation 


\section{Effect of agitation intensity:}

To study the effect of Agitation intensity, optimized batch (P4) was subjected to dissolution in Phosphate buffer 6.8 at 50,75 and $100 \mathrm{rpm}$. There was no significant difference in the release profile of the system with change in agitation intensity.

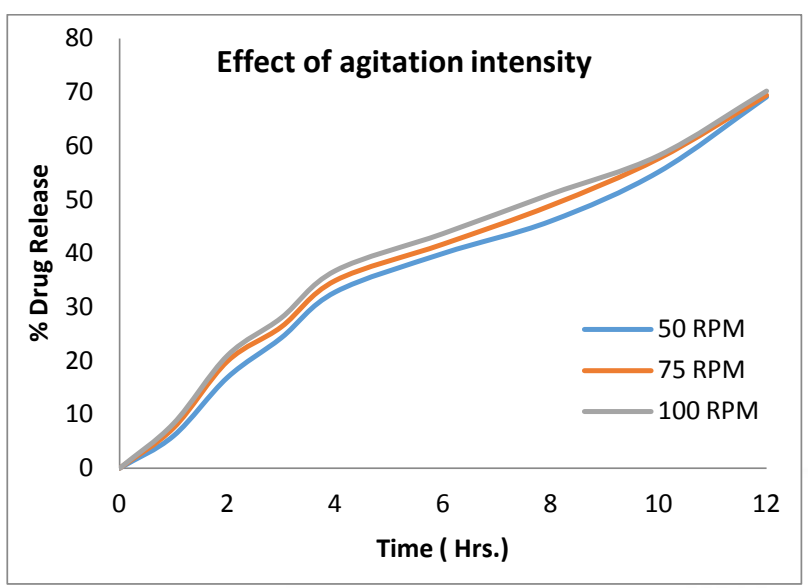

Figure 8: Influence of agitation intensity on drug release of optimized formulation

\section{SEM of Coating (before and after dissolution)}

The coating membrane of the osmotic delivery system before and after dissolution was examined with the help of SEM. Before dissolution (Figure 9a) no pores were found in the coating membrane. But after dissolution (Figure9 b) comparatively more numbers of pores were found in the membrane might be due to leaching or removal of entrapped drug from the formulation. The porous nature of the membrane was due to the presence of pore forming agent HPMC in the formulation.

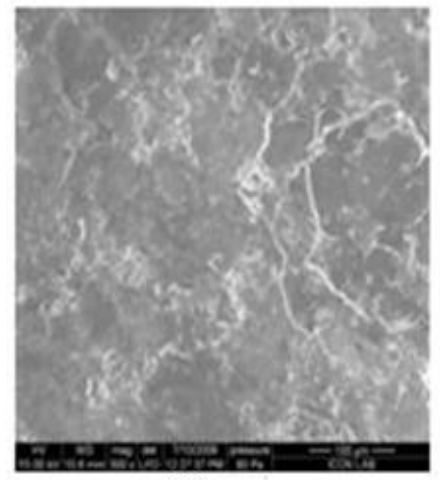

(a)

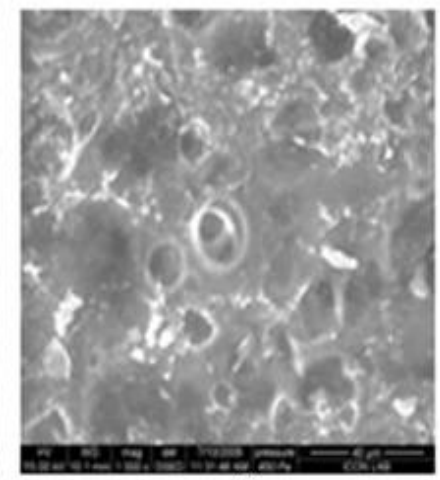

(b)
Figure 9: SEM Micrographs of the coat, a) before dissolution b) after dissolution ( $24 \mathrm{~h}$ ) after dissolution

\section{Stability study:}

The optimized formulation was maintained at $40^{\circ} \mathrm{C}$ and $75 \%$ RH for 6 months. The tablets were evaluated for their appearance, drug content and dissolution profile. The results revealed that there was no significant change in the parameters. Therefore, the formulation $\mathrm{P} 4$ is considered to be stable.

Table 6: Stability study

\begin{tabular}{|c|c|c|c|c|c|}
\hline \multirow{2}{*}{ Parameters } & \multicolumn{5}{|c|}{ Optimized Formulation (P4) } \\
\cline { 2 - 7 } & Initial & 1 month & 2 months & 3 months & 6 months \\
\hline Visual appearance & No Change & No Change & No Change & No Change & No Change \\
\hline Drug content & $99.98 \pm 0.018$ & $99.89 \pm 0.62$ & $99.85 \pm 0.43$ & $98.82 \pm 0.34$ & $97.11 \pm 0.14$ \\
\hline \% Release & $98.56 \pm 0.82$ & $97.57 \pm 0.79$ & $97.18 \pm 0.84$ & $96.96 \pm 0.88$ & $96.90 \pm 0.32$ \\
\hline
\end{tabular}

\section{CONCLUSION}

A porous osmotic pump-based drug delivery system can be designed for extended release of Garcinia indica extract. It is evident from the results that the rate of drug release can be controlled through osmotic pressure of the core, level of pore former, and membrane weight with release to be fairly independent of $\mathrm{pH}$ and hydrodynamic conditions of the body. The drug release from the developed formulations was inversely proportional to the membrane weight gain and directly proportional to the concentration of osmogen and the pore forming agent. Results of SEM studies confirmed the formation of pores in the membrane after coming into contact with the aqueous environment. Hence this can be used to develop newer formulations to avoid shortcomings of conventional dosage forms.

\section{ACKNOWLEDGEMENT}

I wish to express my sincere gratitude to Principal Dr. (Mrs.) Kiran Bhise and the Management, of M.C.E. Society's Allana College of Pharmacy, Pune for giving me an opportunity to carry out the research work and for their support throughout the work. I would like to express my gratitude towards my Co-supervisor Dr. Vijayalakshmi Prakya, Principal, Siddhartha Institute of pharmacy, Hyderabad and Jawaharlal Nehru Technical University, Hyderabad, Telangana, India for continuous support and guidance. 


\section{REFERENCES}

1. Chein YW. Novel Drug Delivery Systems ed by Chein YW, Marcel Dekker, Inc., New York, USA 1992; 139-196.

2. Verma RK, Krishna DM, Garg S. 'Formulation Aspects In The Development Of Osmotically Controlled Oral Drug Delivery Systems.'J Control Rel., 2002; 7(9):7-27.

3. Zentner GM, Rork GS, Himmelsteic KJ., Controlled Porosity Osmotic Pump , U.S. Patent 1999

4. Liu L, Ku J, Khang G, Lee B, Rhee JM, Lee HB. 'Nifedipine Controlled Delivery by Sandwiched Osmotic Tablet System.' J Control Rel., 2000; 6(8):145-156.

5. Makhija S. N, Vavia P. R. Controlled Porosity Osmotic PumpBased Controlled Release System of Pseudoephedrine. ', J Control Rel, 2003; 8(9):5-18.

6. Sahoo C. K., Rao SRM, Sudhakar M. 'Formulation and Evaluation of Controlled Porosity Osmotic Pump Tablets for Zidovudine and Lamivudine Combination using Fructose as Osmogen', Journal of Drug Delivery and Therapeutics, 2017; 7(4):41-50. doi:10.22270/jddt.v7i4.1465

7. Jagtap P., Bhise K., Vijayalakshmi P. 'A Phytopharmacological Review On Garcinia Indica ', International Journal Of Herbal Medicine , 2015; 3(4):02-07

8. Jagtap P., Vijayalakshmi P., Bhise K., 'Phytochemical Characterization And Cytotoxic Evaluation Of Methanolic Extract Of Garcinia Indica Fruit Rind; International J Of Pharmacognosy, 2017; 4(11):372-377

9. Banerjee A, Verma PRP, Gore S. Controlled porosity solubility modulated osmotic pump tablets of Gliclazide.AAPS Pharm Sci Tech 2015; 16(3):554-568.

10. Loftsson $\mathrm{T}$ and Brewster ME. Pharmaceutical application of cyclodextrin in drug solubilisation and stabilization. J Pharm Sci 1996; 85:1017-25.

11. Kamal D, Ramana MD, Himaja M, Agarwal A and Garg V. Investigation of enhancement of solubility of norfloxacin beta cyclodextrin in presence of acidic solubilizing additives. Curr Drug Deliv 2007; 4:21-5.

12. Ghosh T., Ghosh A., Thimmasetty J., Development and Biopharmaceutical Evaluation of Controlled Porosity Osmotic Formulations of Silymarin $\beta$-Cyclodextrin Inclusion Complex, Ijppr.Human, 2016; 7 (1):276-292.
13. Mehramizi A., Asgari Monfared E., Pourfarzib M., Bayati Kh. 'M Influence of B-Cyclodextrin Complexation on Lovastatin Release From Osmotic Pump Tablets (OPT) ',DARU, 2007; 15(2):71-78.

14. Padhye S, Ahmad A, Oswal N. and Sarkar FH, 'Emerging Role of Garcinol, the antioxidant Chalcone From Garcinia indica Choisy and Its Synthetic Analogs', Journal of Hematology \& Oncology, 2009; 2(3):1-13.

15. Jagtap P., Awargaonkar A, Kuchekar S., Bhise K 'Formulation and Evaluation of Controlled Porosity Osmotic Pump Tablet of Ranitidine Hydrochloride Research Journal of Pharmacy and Technology, 2010; 3(4):1205-1208.

16. Nikhil P. Mahalpure, Sheetal B. Gondkar, Shalaka P. Rasal, Ravindra B. Saudagar 'Development of Controlled Porosity Osmotic Pump Tablet Of Linagliptin ', World Journal Of Pharmacy And Pharmaceutical Sciences, 2017; 6(6):765-777

17. Elchidana PA, Deshpande SG 'Microporous Membrane - Drug Delivery System for Indomethacin. J. Controlled Release, 1999, 5(9):279-285

18. Verma RK, Garg S. 'Development and Evaluation of Osmotically Controlled Oral Drug Delivery System of Glipizide.' European Journal of Pharmaceutics and Biopharmaceutics, 2004; 5(7):513-525.

19. Rahul D., Kumar A. And Pathak K.'Solubility-Modulated Asymmetric Membrane Tablets Of Triprolidine Hydrochloride: Statistical Optimization and Evaluation AAPS Pharmscitech, 2012; 13(1):1-8.

20. Moore JW, Flanner HH 'Mathematical Comparison of Dissolution Profiles. Pharm Technol, 1996; 20:64-74.

21. Kumaravelrajan R, Narayanan N, Suba V. 'Development and Evaluation of Controlled Porosity Osmotic Pump For Nifedipine And Metoprolol Combination. Lipids in Health and Disease, 2011; 10(5):1-10.

22. Kanagale P.,Lohray B., Misra A. 'Formulation And Optimization Of Porous Osmotic Pump-Based Controlled Release System Of Oxybutynin', 2007; 8(3):1-7

23. Cartensen JT. Drug stability: Principle and practices, Marcel Dakker, New York, 2nd ed. 1995; 538-550. 